\title{
Identification, Characterization, and Detection of Black raspberry necrosis virus
}

\author{
Anne Halgren, Ioannis E. Tzanetakis, and Robert R. Martin
}

First, second, and third authors: Department of Botany and Plant Pathology and Center for Genome Research and Biocomputing, Oregon State University, Corvallis; and third author: U.S. Department of Agriculture-Agricultural Research Service, Horticultural Crops Research Laboratory, Corvallis, OR.

Accepted for publication 31 July 2006.

\begin{abstract}
Halgren, A., Tzanetakis, I. E., and Martin, R. R. 2007. Identification, characterization, and detection of Black raspberry necrosis virus. Phytopathology 97:44-50.

A serious disease was observed in black raspberry (Rubus occidentalis) in Oregon in the last decade. Plants showing mosaic symptoms declined rapidly and, in many cases, died after several years. Double-stranded RNA extraction from symptomatic black raspberry revealed the presence of two high molecular weight bands which were cloned and sequenced. Sequence analysis disclosed the presence of a novel virus that was tentatively named Black raspberry decline-associated virus (BRDaV). The complete sequences of the two genomic RNAs, excluding the $3^{\prime}$ polyadenosine tails, were 7,581 and 6,364 nucleotides, respectively. The genome organization was identical to that of Strawberry mottle virus, a

member of the genus Sadwavirus. The C terminus of the RNA 1 polyprotein is unique within the genus Sadwavirus, with homology to AlkBlike domains, suggesting a role in repair of alkylation damage. A reversetranscriptase polymerase chain reaction test was designed for the detection of BRDaV from Rubus tissue, and tests revealed that BRDaV was associated consistently with the observed decline symptoms. While this publication was under review, it came to our attention that scientists at the Scottish Crop Research Institute had molecular data on Black raspberry necrosis virus (BRNV), a virus that shared many biological properties with BRDaV. After exchange of data, we concluded that BRDaV is a strain of BRNV, a previously described yet unsequenced virus. The North American strain was vectored nonpersistently by the large raspberry aphid and the green peach aphid. Phylogenetic analysis indicates that BRNV belongs to the genus Sadwavirus.
\end{abstract}

Black raspberry decline (BRD) is a disease of major concern to black raspberry (Rubus occidentalis L.) growers in Oregon (16), where nearly $100 \%$ of the black raspberry production in the United States occurs (37). Black raspberry plants affected by the disease initially display leaf chlorosis and puckering (Fig. 1). Symptom expression and severity are not related to topography, suggesting that Phytophthora spp. are not the cause of the disease. Eventually, the fruiting canes prematurely die back, resulting in rapid and severe reduction in yield. Although a healthy black raspberry planting should last several decades if maintained properly, those affected with BRD typically are in production for three or four growing seasons before they succumb to disease and no longer remain profitable. A single cultivar, Munger, is grown predominantly in Oregon. Several other black raspberry cultivars in production demonstrate very little genetic diversity (51), and also succumb to BRD.

BRD was suspected to be caused by previously unidentified viruses infecting Rubus spp., or a component of raspberry mosaic disease (47), which consists of Rubus yellow net virus (45), Black raspberry necrosis virus (BRNV) (46), Raspberry leaf mottle virus (5), or Raspberry leaf spot virus (6). The etiology of raspberry mosaic disease is complex and poorly understood. All identified members of the complex can be detected by petiole leaflet grafting into different cultivars of Rubus spp. (22). All viruses of the complex, with the exception of Rubus yellow net

Corresponding author: A. Halgren; E-mail address: halgren@gmail.com

* The $\boldsymbol{e}$-Xtra logo stands for "electronic extra" and indicates that Figure 1 appears in color online.

DOI: 10.1094/PHYTO-97-0044

This article is in the public domain and not copyrightable. It may be freely reprinted with customary crediting of the source. The American Phytopathological Society, 2007 virus, have been described solely on the basis of symptom expression, experimental host range, and vector relations. It was speculated (R. R. Martin, personal observation) that BRD may be caused by BRNV because of the observed field symptomatology; however, the characteristic tip necrosis of black raspberry plants infected with BRNV did not develop when grafted onto indicators (16). Early attempts to purify BRNV were thwarted by low virus yields (24,34). Jones and Mitchell (23) produced antiserum against BRNV in mixed infection with a co-infecting virus; however, the supply has been exhausted.

This report identifies a virus consistently associated with declining black raspberry plants, which was named Black raspberry decline-associated virus (BRDaV). While the present communication was under review, it came to our attention that scientists at the Scottish Crop Research Institute had obtained a partial sequence of BRNV. After an exchange of data, we realized that $\mathrm{BRDaV}$ is a strain of BRNV, and this name will be used hereafter to describe the virus. The biological and molecular properties of BRNV are described, and data suggest BRNV is a new member of the genus Sadwavirus.

\section{MATERIALS AND METHODS}

Test plants and virus isolates. One isolate, BRNV-NA (North American isolate), obtained from a plant of cv. Munger black raspberry, was chosen as the reference isolate for obtaining the nucleotide sequence of BRNV and for aphid transmission studies. Healthy plants for rearing aphids were derived from cuttings of Munger plants that were tested by grafting and enzyme-linked immunosorbent assay (9) and found free of all major Rubus viruses, including Raspberry bushy dwarf virus (RBDV), Tomato ringspot virus (ToRSV), and Strawberry necrotic shock virus (SNSV). Healthy and infected plants were kept in separate green- 
houses. Plants (cv. Munger) for aphid transmission studies were grown from seed of healthy tissue culture-derived plants. Black raspberry plants were maintained in a greenhouse between 16 and $26^{\circ} \mathrm{C}$ with supplemental lighting to maintain at least $14 \mathrm{~h}$ of daylight.

Transmission studies. BRNV-NA was used as inoculum for mechanical transmission to 20 herbaceous hosts in seven different families, including a transgenic tobacco line containing a viral RNA silencing suppressor (43) (Table 1). At least two sets of 16 plants of each species were inoculated. Inoculum was prepared by homogenizing infected black raspberry leaf tissue at an $\approx 1: 50$ dilution in $0.1 \times$ phosphate-buffered saline $(0.02 \mathrm{M}$ phosphate and $0.15 \mathrm{M} \mathrm{NaCl}, \mathrm{pH} 7.4$ ) containing $2 \%$ nicotine (vol/vol). Test plants were dusted with Carborundum powder (600 mesh) prior to inoculations. Inoculum was rubbed lightly onto recipient leaves with a foam pad and rinsed off with tap water after an hour.

Colonies of aviruliferous aphids were maintained in aphid cages in a separate greenhouse under the aforementioned light and temperature settings. Colonies of the large raspberry aphid Amphorophora agathonica (Hottes) and the green peach aphid Myzus persicae (Sulzer) were established by transferring nymphs as they were born to healthy, virus-free black raspberry and Chenopodium quinoa (Willd.), respectively. In order to determine aphid acquisition and transmission times, aphids were fed on detached leaves for $20 \mathrm{~s}$ to $1 \mathrm{~min}, 1 \mathrm{~h}, 5 \mathrm{~h}$, or $24 \mathrm{~h}$. After specified feeding times, 10 aphids were transferred with a fine bristle paintbrush to each of five plants to feed for $20 \mathrm{~s}$ to $1 \mathrm{~min}, 1 \mathrm{~h}, 24$ $\mathrm{h}$, or 7 days for inoculation access. All plants were the same age and at the same stage of growth. Plants were evaluated for virus infection via reverse-transcriptase polymerase chain reaction (RTPCR) at 5 weeks postinoculation.

RT-PCR detection. Total RNA was extracted from plant samples for use in RT-PCR detection using a modified Spiegel and Martin (44) method. Leaf tissue (100 mg) representative of all leaves in the sample was homogenized in $1 \mathrm{ml}$ of extraction buffer (200 mM Tris base, $\mathrm{pH} 8.5,300 \mathrm{mM}$ lithium chloride, $1.5 \%$ lithium dodecyl sulfate, $10 \mathrm{mM}$ EDTA, $1 \%$ deoxycholic acid, 2\% polyvinyl-pyrrolidone, 1\% NP 40 "Tergitol," and $\beta$ mercaptoethanol, added to result in a $1 \%$ solution [vol/vol] just before use). An equal volume of potassium acetate $(2.8 \mathrm{M}$ potassium and $6 \mathrm{M}$ acetate, $\mathrm{pH}$ 6.5) was added to the extract and chilled at $-20^{\circ} \mathrm{C}$ for at least $30 \mathrm{~min}$. After thawing, the mixture was centrifuged at $16,000 \times g$ for $10 \mathrm{~min}$ in a microfuge and $0.7 \mathrm{ml}$ of the supernatant was transferred to a new tube. An equal amount of isopropanol was added and mixed via inversion and centrifuged for $20 \mathrm{~min}$ at $16,000 \times \mathrm{g}$. Finally, the pellet was washed twice with cold $70 \% \mathrm{EtOH}$ and dried briefly under vacuum. The dried pellet was resuspended in $40 \mu \mathrm{l}$ of RNase-free water. RNA constituted 1 to $5 \%$ of cDNA synthesis reaction volume. Typically, a reaction would consist of $\approx 100 \mathrm{ng}$ of total
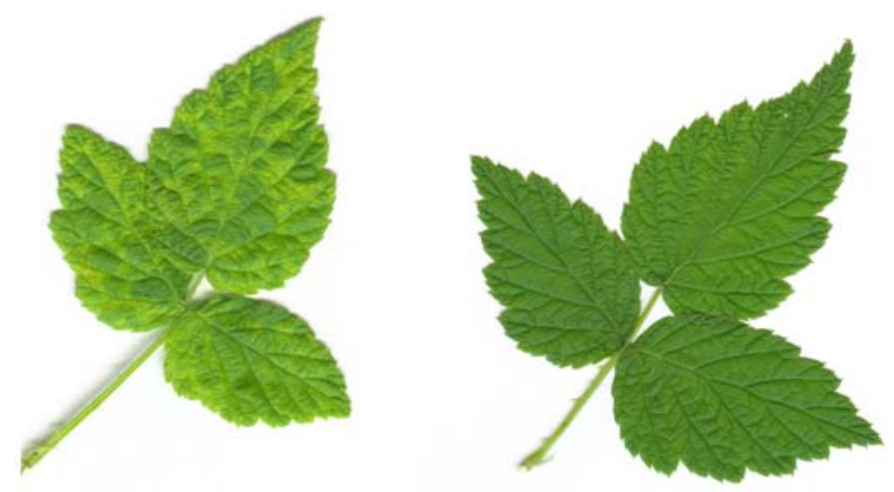

Fig. 1. Left: symptomatic leaf affected with Black raspberry necrosis virus, showing chlorosis, mottling, and puckering. Right: healthy black raspberry leaf.
RNA, $150 \mathrm{ng}$ of random primers, $1 \times$ first-strand buffer, $1 \mathrm{mM}$ dNTPs, $10 \mathrm{mM}$ dithiothreitol (DTT), $16 \mathrm{U}$ of RNase OUT, and $60 \mathrm{U}$ of SuperScript III RT in a final volume of $20 \mu \mathrm{l}$. All enzymes and corresponding buffers were from Invitrogen (Carlsbad, CA). The reaction was incubated for $1 \mathrm{~h}$ at $50^{\circ} \mathrm{C}$. The RT product constituted no greater than $4 \%$ of the total PCR reaction volume to prevent inhibition from plant secondary metabolites carried over from the RNA. PCR reactions were carried out according to the polymerase manufacturer's instructions (Genscript, Piscataway, NJ). Two sets of primers were designed and used in tandem for detection. Primer set 1 amplified a 417-nucleotide (nt) fragment of the RNA-dependent RNA polymerase (RdRp) region of RNA 1, and consisted of forward primer 5'ATGCTGAGCCACTTGTGA3' and reverse primer 5'ATCTGGTGTGTTCCGCAT3'. Primer set 2, forward primer 5'CAATGTCTTGGAAGCCAC3' and reverse primer 5'AGCATGGTTCGTCATCTG3', amplified a 350-nt fragment further downstream at the very $3^{\prime}$ end of the RdRp region. The PCR program for detection consisted of initial denaturation for $5 \mathrm{~min}$ at $94^{\circ} \mathrm{C}$ followed by 40 cycles with denaturation for $30 \mathrm{~s}$ at $94^{\circ} \mathrm{C}$, annealing for $45 \mathrm{~s}$ at $55^{\circ} \mathrm{C}$, and extension for $30 \mathrm{~s}$ at $72^{\circ} \mathrm{C}$, with a final 10 -min extension step at $72^{\circ} \mathrm{C}$. The samples were subjected to electrophoresis through agarose gels containing $10 \mu \mathrm{g} / \mathrm{ml}$ of ethidium bromide, and amplicons were visualized by exposure to a UV light. Amplification of the highly conserved plant gene NADH dehydrogenase ND2 subunit ( $n d h B$ gene) was used as an internal control to verify the quality of the RNA extraction and effectiveness of the RT-PCR (30). This gene consists of two exons separated by one intron; thus, amplicon size reveals whether RNA or DNA was used as a template. To verify the amplification of the viral genes, at least 30 PCR products were sequenced. All PCR reactions were carried out using a Robocycler (Stratagene, La Jolla, CA) thermocycler.

Virus purification. Virus was purified from infected 'Munger' leaf tissue using a modified protocol of Murant et al. $(15,34)$ utilized for BRNV. One-milliliter fractions were collected from the sucrose density gradient and diluted, and the virus was pelleted at $252,000 \times g$ for $60 \mathrm{~min}$ in a Beckman Type 80 Ti rotor. Each pellet was resuspended in $200 \mu \mathrm{l}$ of citrate buffer $(0.05 \mathrm{M}$, pH 6, with $1 \%$ Triton X-100 and $0.2 \%$ thioglycolic acid). Virus also was purified from Nicotiana benthamiana L. and N. occidentalis (Wheeler) adapting a protocol for Tomato ringspot virus purification (48). Each fraction was tested by RT-PCR for the presence of BRNV. The RT-PCR procedure was performed as described above, except that $1 \mu \mathrm{l}$ of the virus preparation served

TABLE 1. Indicator plants used for mechanical transmission of Black raspberry necrosis virus (BRNV)

\begin{tabular}{|c|c|}
\hline Plant name & Family \\
\hline Antirrhinum majus & Scrophulariaceae \\
\hline Beta vulgaris var. cicla ${ }^{\mathrm{a}}$ & Chenopodiaceae \\
\hline Brassica junceaica & Brassicaceae \\
\hline Capsicum annum & Solanaceae \\
\hline Chenopodium amaranticolor & Chenopodiaceae \\
\hline C. quinoa & Chenopodiaceae \\
\hline Cucumis sativus var. sativus & Cucurbitaceae \\
\hline Datura stramonium & Solanaceae \\
\hline Glycine max & Fabaceae \\
\hline Lactuca sativa & Asteraceae \\
\hline Nicotiana benthaniana ${ }^{\mathrm{a}}$ & Solanaceae \\
\hline N. clevelandii & Solanaceae \\
\hline N. occidentalis ${ }^{\mathrm{a}}$ & Solanaceae \\
\hline N. rustica ${ }^{\mathrm{a}}$ & Solanaceae \\
\hline N. tabacum ${ }^{\mathrm{a}}$ & Solanaceae \\
\hline N. tabacum-HC Pro mutant ${ }^{\mathrm{a}}$ & Solanaceae \\
\hline Phaseolus vulgaris & Fabaceae \\
\hline Pisum sativum & Fabaceae \\
\hline Spinacia oleracea & Chenopodiaceae \\
\hline Vigna unguiculata subsp. unguiculata ${ }^{\mathrm{a}}$ & Fabaceae \\
\hline
\end{tabular}

a Indicates species tested positive for BRNV. 
as template for the RT reaction, and viral RNA, water, and primer components all were incubated at $70^{\circ} \mathrm{C}$ prior to combination with remaining components of the first-strand cDNA synthesis reaction. Fractions testing positive were sent to the electron microscope facility for analysis, where they were stained with $2 \%$ ammonium molybdate and viewed by a Philips CM-12 scanning transmission electron microscope.

cDNA synthesis and cloning. Fresh and frozen black raspberry tissue collected in the spring and fall from a severely infected field was used originally as source material for double-stranded RNA (dsRNA). Total RNA and dsRNA from BRNV-NA later was used to confirm the entire sequence of the virus. For dsRNA isolation, a modified Yoshikawa and Converse (52) method was used (15).

Synthesis of cDNA was performed using dsRNA as a template. dsRNA combined with $0.3 \mu \mathrm{g}$ of random hexanucleotides (Invitrogen) was denatured in the presence of $20 \mathrm{mM}$ methylmercury (II) hydroxide, as described (21). The reverse transcriptase mixture was added to the denatured dsRNA to create a total volume of $50 \mu \mathrm{l}$, which contained cDNA synthesis buffer, $1 \mathrm{mM}$ dNTPs, $10 \mathrm{mM}$ DTT, $40 \mathrm{U}$ of RNase OUT, and $15 \mathrm{U}$ of Thermoscript. All enzymes and corresponding buffers were from Invitrogen. The mixture was incubated for $5 \mathrm{~min}$ at room temperature, then $1 \mathrm{~h}$ at $60^{\circ} \mathrm{C}$. First-strand cDNA was precipitated with $1 / 10$ volume of $3 \mathrm{M}$ NaAcetate and 2.5 volumes ( $\mathrm{vol} / \mathrm{vol})$ of $100 \% \mathrm{EtOH}$. The precipitated, washed, and dried cDNA pellet was suspended in a total volume of $100 \mu \mathrm{l}$, containing Escherichia coli ligase buffer, $10 \mathrm{U}$ of $E$. coli ligase, $1 \mathrm{mM}$ dNTPs, $15 \mathrm{U}$ of $E$. coli DNA polymerase I, and $1 \mathrm{U}$ of RNase $\mathrm{H}$. All enzymes and corresponding buffer were from New England Biolabs (Ipswich, MA). The reaction was incubated for $1 \mathrm{~h}$ at $12^{\circ} \mathrm{C}$ and $1 \mathrm{~h}$ at $22^{\circ} \mathrm{C}$. cDNA then was adenylated using $1 \mathrm{U}$ of $\mathrm{Taq}$ polymerase and $0.2 \mathrm{mM}$ dATP for $20 \mathrm{~min}$ at $72^{\circ} \mathrm{C}$. cDNA then was purified using the rapid PCR purification system (Novagen, Madison, WI), cloned into the pCR4 TOPO vector (Invitrogen), and transformed into DH5 $\alpha$ E. coli cells (Invitrogen). Plasmids were purified, digested with EcoRI (New England Biolabs), and analyzed via agarose gel electrophoresis.

Genome acquisition. Total RNA was extracted from BRNVNA-infected plants for use in RT-PCR to fill in the sequence gaps between clones obtained from shotgun cloning. RT reactions were performed with random primers, as described above, for use in multiple PCR reactions. PCR primers were developed based on the sequence adjacent to the gaps. The PCR programs consisted of an initial denaturation at $94^{\circ} \mathrm{C}$ for $5 \mathrm{~min}$, followed by 40 cycles of $94^{\circ} \mathrm{C}$ for $30 \mathrm{~s}$, varying temperatures for annealing for $30 \mathrm{~s}$, and extension of varying times at either $68^{\circ} \mathrm{C}$ if using Takara La Taq (Takara Mirus Bio, Madison, WI) or $72^{\circ} \mathrm{C}$ using Genscript Taq polymerase.

The sequences of the $5^{\prime}$ and $3^{\prime}$ termini of RNA 1 and RNA 2 were determined using rapid amplification of cDNA ends (RACE) reactions. This involved poly-adenylating the dsRNA template (to

TABLE 2. Transmission of Black raspberry necrosis virus (BRNV) by Amphorophora agathonica and Myzus persicae ${ }^{\mathrm{a}}$

\begin{tabular}{lccccc}
\hline & \multicolumn{2}{c}{ Access time } & & \multicolumn{2}{c}{$\begin{array}{c}\text { No. of infected plants/ } \\
\text { plants fed on }\end{array}$} \\
\cline { 2 - 3 } \cline { 5 - 6 } Treatment no. & Acquisition & Inoculation & & A. agathonica & M. persicae \\
\hline 1 & $20 \mathrm{~s}$ to $1 \mathrm{~min}$ & $20 \mathrm{~s}$ to $1 \mathrm{~min}$ & & $1 / 5$ & $2 / 5$ \\
2 & $1 \mathrm{~h}$ & $1 \mathrm{~h}$ & & $4 / 5$ & $3 / 5$ \\
3 & $5 \mathrm{~h}$ & $24 \mathrm{~h}$ & & $2 / 5$ & $0 / 5$ \\
4 & $24 \mathrm{~h}$ & $24 \mathrm{~h}$ & & $5 / 5$ & $0 / 5$ \\
5 & $24 \mathrm{~h}$ & 7 days & & $3 / 5$ & $0 / 5$ \\
\hline
\end{tabular}

a Aphids fed on a detached leaf from a 'Munger' plant infected with the North American isolate of BRNV for indicated times. After feeding, 10 aphids were transferred to each of five plants to feed for indicated times. Plants were tested for virus by reverse-transcriptase polymerase chain reaction at 5 weeks postinoculation. obtain the $5^{\prime}$ end) (42), first-strand synthesis with methylmercury (II) hydroxide (21) using a universal anchored primer (5'GACTCGAGTCGACATCGA $\left.(\mathrm{T})_{17} 3^{\prime}\right)$, and nested PCR using a sequence specific primer and a poly-thymidine primer as described previously (50). The $5^{\prime}$ end of the RNA 1 and RNA 2 was confirmed via poly-deoxycytosine tailing using the 5' RACE System kit (version 2.0; Invitrogen) with total nucleic acid as a template. Amplification of all termini using both protocols was performed twice.

Sequencing and genome analysis. All clones and PCR products were sequenced with an ABI 3730XL DNA sequencer at Macrogen, Inc. facilities (Seoul, Korea), identified using BLAST (2), and analyzed using CAP3 software (18). Open reading frames (ORFs) were analyzed using the National Center for Biotechnology Information ORF finder. Conserved domains were identified using CD-Search (29). The amino acid similarity of the putative BRNV proteins and orthologous proteins of related viruses was calculated using MatGAT (7). PCR products and clones generated from each reaction were sequenced at least twice in both directions. The nucleotide sequence data of BRNV have been deposited to the GenBank nucleotide sequence database and have been assigned the accession numbers DQ344639 and DQ344640 for RNA 1 and 2, respectively. GenBank accessions of related viruses were obtained using BLAST. Multiple alignments and phylogenies were constructed with the CLUSTALW program (49) with its default parameters, after bootstrapping in 1,000 pseudoreplicates. Cluster algorithm phylogenetic trees in Phylip tree format of conserved protease (Pro), helicase (Hel), and $\mathrm{RdRp}$ motifs were visualized with TreeView (38).

\section{RESULTS}

Transmission studies. Of the 20 mechanically inoculated indicator plants, 7 tested positive for BRNV and all plants that tested positive were asymptomatic. BRNV systemically infected $N$. benthamiana, $N$. occidentalis, N. rustica, N. tabacum, N. tabacum HC-Pro mutant, Vigna unguiculata, and Beta vulgaris (Table 1).

Symptoms on black raspberry plants inoculated using $M$. persicae and $A$. agathonica developed $\approx 1$ month postinoculation. All symptomatic plants tested positive for BRNV. At least one plant from every treatment time interval with $A$. agathonica tested positive, whereas only plants from the two shortest acquisition and transmission time intervals with $M$. persicae tested positive. The results of the transmission experiments are shown in Table 2.

Detection by RT-PCR. BRNV was detected in nine of nine sampled declining commercial black raspberry fields in Oregon. None of the healthy black raspberry controls gave BRNV-specific amplicons, whereas PCR with the NADH dehydrogenase ND2 subunit-specific control primers did result in amplicons, verifying the effectiveness of the RT-PCR. All sequenced BRNV amplicons were virus specific.

Virion properties. Electron microscopy of purified virus preparations revealed isometric particles of $\approx 35 \mathrm{~nm}$ in diameter (Fig. 2A). The particles were hexagonal and appeared as empty or full. Purification from $N$. occidentalis and $N$. benthamiana gave low numbers of virions. Purification attempts from $V$. unguiculata (cowpea) were unsuccessful. Though recalcitrant and low yielding, black raspberry was the most reliable host for purification. RT-PCR on individual fractions served as a useful indicator for those that contained viral RNA (Fig. 2B).

Nucleotide sequence and phylogenetic analysis. dsRNA extraction from declining black raspberry revealed two major bands of $\approx 8$ and $7 \mathrm{kbp}$ based on agarose gel electrophoresis (Fig. 3). Analysis of the sequence obtained from the cloning of dsRNA showed the virus to be related to Strawberry mottle virus (SMoV) (50). Based on this information and alignment with SMoV, primers were designed and used in RT-PCR to fill in the gaps between nonoverlapping clones. 
The 5' noncoding regions of RNA 1 and RNA 2 of BRNV were 146 and 223 nt long, respectively, with the first $42 \mathrm{nt}$ being identical. This identity is similar to that reported for SMoV (50). Also characteristic of SMoV and the Comoviridae, the 3' noncoding regions of both RNAs share high sequence identity (94\%).

RNA 1 was 7,581 nt long, excluding the $3^{\prime}$ polyadenosine (poly (A)) tail. The molecule encoded a single ORF that presumably was cleaved proteolytically into its respective functional proteins. ORF 1 was predicted to begin at the first AUG initiation codon that is in good translational context (GAAGAUGUCGU) (28) (nucleotides 147 to 149) and terminate at UAA (nucleotides 6,636 to 6,638 ), yielding a putative polypeptide with molecular weight (MW) of $242 \mathrm{kDa}$.

The polyprotein encoded by RNA 1 probably was cleaved into five functional proteins involved in replication: a putative protease cofactor (Pro-C), Hel, viral genome-linked protein (VPg), Pro, and RdRp. Alignment of the entire 242-kDa protein with the corresponding polyprotein of other closely related viruses suggested the most likely locations for cleavage sites. The resulting most likely dipeptide proteolytic cleavage sites are shown in Figure 4. This is partially in line with the cleavage specificity of 3C-like proteases, which cleave primarily between Q (or E), and G (or S) dipeptides (39). The predicted MW of the mature proteins is given in Table 3.

The $\mathrm{N}$ terminus region of the polyprotein encodes the Pro- $\mathrm{C}$ (Table 3), which was related most closely with the SMoV Pro-C, having $48 \%$ amino acid sequence identity. The conserved amino acid motif $\mathrm{Fx}_{27} \mathrm{Wx}_{11} \mathrm{Lx}_{21} \mathrm{LxE}$ (40) identified within the Pro-C region of some Comoviridae was not detected within the corresponding region of BRNV. Following Pro-C, the helicase (Table 3) aligned most closely with $\mathrm{SMoV} \mathrm{Hel}$, with $72 \%$ amino acid sequence identity in a conserved 200-amino-acid (aa) overlap, and more distantly with Satsuma dwarf virus (SDV), with $42 \%$ sequence identity in the same region. The highly conserved helicase domains A (GKS), B (DE), and C (N) (13) were found at amino acid positions 577-9, 623-4, and 673. Alignment and phylogenetic analysis of these conserved motifs (amino acids 577 to 673) grouped BRNV most closely with SMoV and SDV among viruses of the genus Sadwavirus. The putative VPg (Table 3) showed sequence similarity only with $\mathrm{SMoV}$, with $50 \%$ amino acid identity. The consensus sequence E/D- $\mathrm{x}_{1-3}-\mathrm{Y}-\mathrm{x}_{3}-\mathrm{N}-\mathrm{x}_{4-5}-\mathrm{R}$ found among some comoviruses and nepoviruses (32) was found partially in the putative VPg of BRNV. $\mathrm{E}-\mathrm{x}_{3}-\mathrm{Y}$ was present, but the latter half of the consensus was missing and did not fit the modified scheme proposed by Thompson et al. (50). The closest sequence identities in a 234-aa overlap within the putative protease protein (Table 3 ) were with SMoV (26\%), SDV (22\%), and Navel orange infectious mottling virus (NIMV), a virus sero- logically related to SDV, with $21 \%$. Alignment of the BRNV putative protease with proteases of related viruses revealed the presence of conserved cysteine protease motifs (12). The amino acids $\mathrm{H}, \mathrm{D}$, and $\mathrm{C}$ of the $3 \mathrm{C}$ protease catalytic triad were located at residues 1100, 1164, and 1230. Phylogenetic analysis of BRNV amino acids 1214 to 1257 with corresponding sequence in related viruses revealed clustering of BRNV with SMoV and SDV of the sadwaviruses.

The final region within the 242-kDa ORF was the putative RdRp (Table 3), that had amino acid sequence identities in a 268-aa conserved overlap of 77, 48, and 47\% with SMoV, SDV, and NIMV, respectively. The BRNV RdRp clustered with supergroup I of positive-strand RNA viruses, and contained the conserved RdRp motifs I to VIII $(26,27)$. A conserved domain between amino acids 1,338 and 1,817 detected by the Conserved Domain Database (29) encompassing the eight motifs was aligned with corresponding sequences in related viruses. These domains, as well as the conserved domains of the Pro and Hel, were merged and aligned with those of related viruses to generate a phylogenetic tree (Fig. 5). Two distinct clades emerged, one containing branches for the family Comoviridae and the other containing members of the family Sequiviridae and genus Sadwavirus.

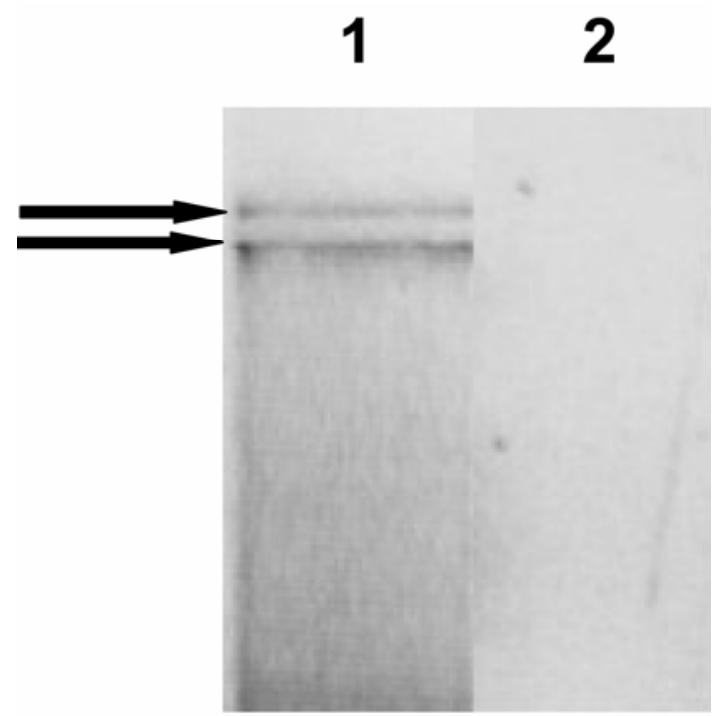

Fig. 3. Double-stranded (ds)RNA extracted from plants infected with Black raspberry necrosis virus (BRNV). Arrows on figure left indicate the position of the dsRNA doublet of $\approx 8$ and $7 \mathrm{kbp}$. Lane 1 : dsRNA purified from greenhouse-grown black raspberry infected with BRNV; lane 2: dsRNA extracted from a healthy black raspberry plant.
A

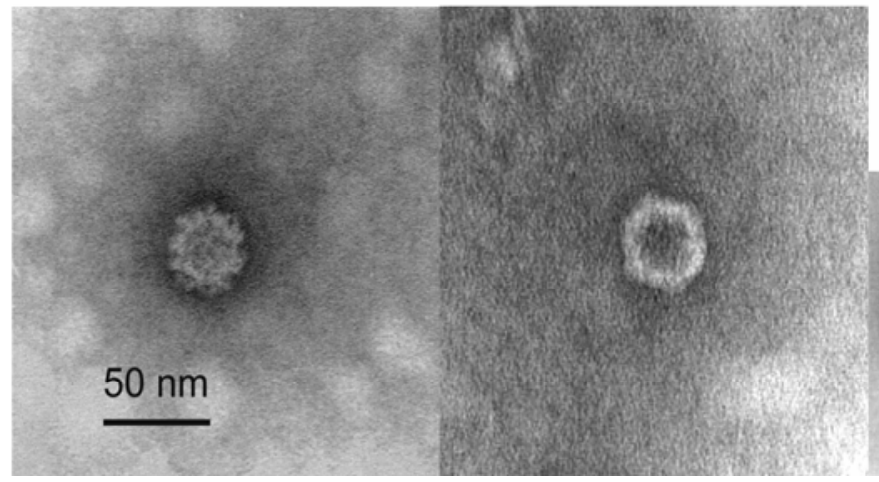

B

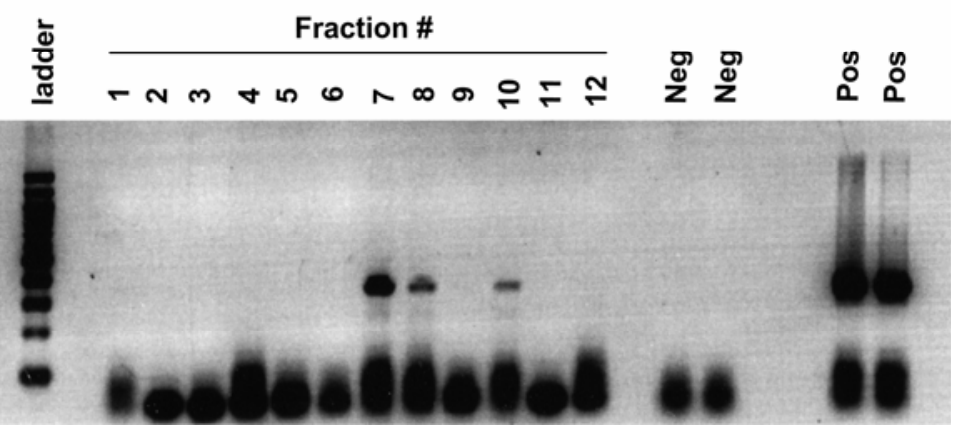

Fig. 2. A, Micrograph of both a closed and open virus-like particle purified from black raspberry decline-infected black raspberry. Bar represents $50 \mathrm{~nm}$ for both particles. B, Detection reverse-transcriptase polymerase chain reaction on virion fractions from sucrose gradients. Twelve fractions were collected from the sucrose gradient of a Black raspberry necrosis virus purification from black raspberry. First lane represents 100-bp ladder (NEB). 
A unique feature of the BRNV RdRp, compared with other related viruses, is an unusual $\mathrm{C}$ terminus (Fig. 4). Where alignment with SMoV ends at the very $\mathrm{C}$ terminal of SMoV, a 189-aa region begins. This region contains a motif homologous to the polymerase fragments of Flexiviridae and Closteroviridae members. Most closely related are the Little cherry virus 2, Cherry green ring mottle virus, and Grapevine virus A orthologous regions. Specifically, the conserved domains within this region correspond to AlkB, an alkylated DNA and RNA repair protein recently shown to be a member of the 2OG-Fe(II) oxygenase superfamily (3).

RNA 2 consisted of 6,364 nts and its predicted single ORF encoded a 1,734-aa polyprotein. The predicted initiation codon, $\mathrm{AUG}_{224-6}$, like that of RNA 1 , has a purine in the -3 position and is in good but not excellent translational context (28). The predicted ORF terminates at UAG (nucleotides 5200 to 5202), yielding a 194-kDa polypeptide.

The polyprotein encoded by RNA 2 likely was cleaved to give rise to three mature proteins: a movement protein (MP) and the large and small coat proteins ( $\mathrm{CPl}$ and $\mathrm{CPs}$, respectively). The most probable cleavage sites in RNA 2, based on alignments with $\mathrm{SMoV}$, are shown in Figure 4. One EQG, the dominant cleavage motif within SMoV (50), was found at residues 907 to 909, as well as three other $\mathrm{Q} / \mathrm{G}$ dipeptides and eight $\mathrm{E} / \mathrm{G}$ dipeptides.

When the first putative protein, MP (Table 3), was used as the query in a BLAST search, only the MP of SMoV, with $42 \%$ sequence identity in a 279 -aa overlap, was identified. A conserved sequence motif (amino acids 182 to 214 ) found in the $30 \mathrm{~K}$ superfamily of plant virus movement proteins (35) was identified and aligned with MPs of closely related viruses. There was conservation of the $30 \mathrm{~K}$ superfamily $\mathrm{LxD}$ motif in BRNV, and the first common motif, LxP (amino acids 24 to 26) was present (33). Consensus between BRNV and the family Sequiviridae was marginal, but slightly greater with the family Comoviridae. CPl (Table 3) aligned most closely with $\mathrm{SMoV}$, with $42 \%$ sequence identity in a 921-aa overlap, but very little with other Satsuma dwarf-related viruses. Though better known for their conservation of secondary structure than amino acid motifs (11), a 47-aa region of BRNV $\mathrm{CPl}$ was aligned with a previously identified $\mathrm{CP}$ region conserved among several calici-, picorna- and sequiviruses (25). This alignment revealed a universally conserved glycine residue among all viruses compared, whereas several other motifs were conserved specifically among sadwaviruses, Sequiviridae, or comoviruses (data not shown). CPs (Table 3) showed significant similarity only with SMoV, with $24 \%$ sequence identity in a 264-aa overlap.

\section{DISCUSSION}

BRNV has sequence and genome organization closest to that of SMoV (50), a member of the genus Sadwavirus (31). Both viruses share long $3^{\prime}$ noncoding regions, a characteristic shared with some nepoviruses (41) but which sets them apart from the Sadwavirus type member, SDV (19,20). Until recently, this unclassified genus had been termed "SDV-like viruses," consisting of members with genomic similarity to SDV yet with no consistency of vector. Like the nepoviruses, sadwaviruses have a singlestranded, positive-sense RNA, bipartite genome. Furthermore, the genomes of both genera are encapsidated in icosahedral particles, and each RNA produces a proteolytically cleaved polyprotein. RNA 1 encodes replication-related proteins, whereas RNA 2 encodes the cell-to-cell MP and CPs. Unlike the nepoviruses, however, sadwaviruses produce two distinct CPs, a feature shared with the faba- and comoviruses.

Although the BRNV genome organization closely resembles viruses of the family Comoviridae, the RdRp is related to viruses both among and outside of the sadwaviruses and the families Sequiviridae and Comoviridae. BLAST searches reveal relationships with Cherry rasp leaf virus of the newly established unassigned Cheravirus genus (31) and more remote viruses such as Acute bee paralysis virus (14), Kashmir bee virus (10) of the unassigned Dicistroviridae, and Varroa destructor virus 1 (36), a virus of mites in the unassigned genus Iflavirus. This relatedness among seemingly diverse viruses supports the growing concept of

TABLE 3. Position on genome and size of proposed functional proteins of Black raspberry necrosis virus, North American isolate ${ }^{\mathrm{a}}$

\begin{tabular}{lccc}
\hline Region & Nucleotide positions & $\begin{array}{c}\text { No. of amino } \\
\text { acids }\end{array}$ & $\begin{array}{c}\text { Molecular mass } \\
(\mathrm{kDa})\end{array}$ \\
\hline Pro-C & $147-1691$ & 515 & 56.2 \\
Hel & $1692-3206$ & 505 & 56.9 \\
VPg & $3207-3284$ & 26 & 2.8 \\
Pro & $3285-3986$ & 234 & 25.4 \\
RdRp & $3987-6638$ & 883 & 100.7 \\
MP & $224-1195$ & 324 & 36.1 \\
CPl & $1196-3958$ & 921 & 102.7 \\
CPs & $3959-5425$ & 488 & 55.2 \\
\hline
\end{tabular}

${ }^{\text {a }}$ Pro- $\mathrm{C}=$ putative protease cofactor, $\mathrm{Hel}=$ helicase, $\mathrm{VPg}=$ viral genomelinked protein, Pro = protease, $\mathrm{RdRp}=$ RNA-dependent RNA polymerase, $\mathrm{MP}=$ movement protein, and $\mathrm{CPl}$ and $\mathrm{CPs}=$ large and small coat proteins, respectively.

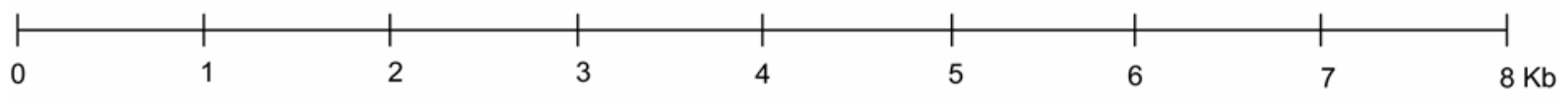

RNA 1

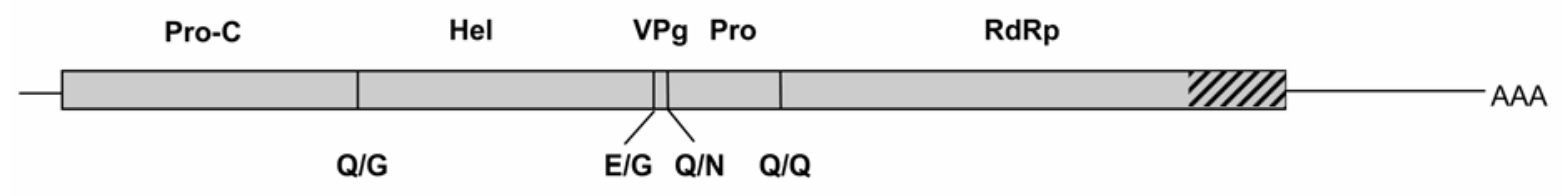

RNA 2

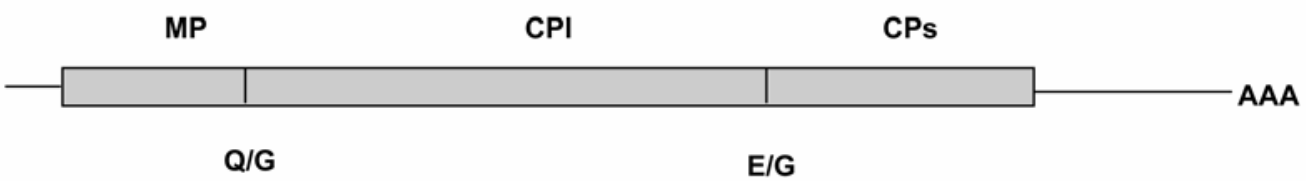

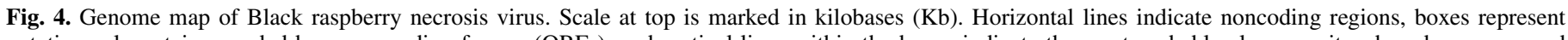

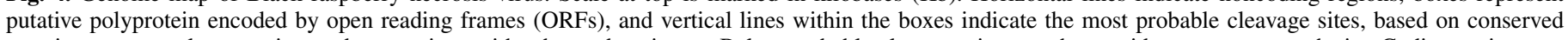

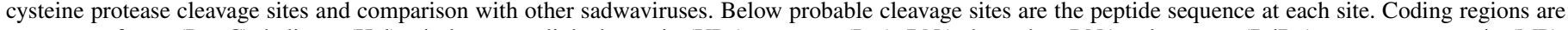

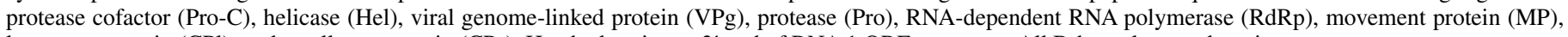
large coat protein (CPl), and small coat protein (CPs). Hatched region at $3^{\prime}$ end of RNA 1 ORF represents AlkB-homologous domain. 
the picorna-like virus "superfamily." Genomes within this grouping share the same replicative core proteins, in the order HelVPg-Pro-RdRp, having a type III helicase domain and a type I polymerase domain (27). Further defining characteristics include similarities in RNA termini, involving a $3^{\prime}$ poly(A) tail (with the exception of the genus Sequivirus) and a covalently linked VPg at the $5^{\prime}$ end, and a $3 \mathrm{C}$-like cysteine protease (12). Based on these affinities, the International Committee on Taxonomy of Viruses recently proposed the creation of an order, termed Picornavirales, which would include those viruses of vertebrates, plants, and insects sharing similar replicative gene blocks and expression mechanisms, and encompassing the sadwaviruses (8). Karasev et al. (25) suggested that an SDV-like lineage likely occurred by the splitting of an ancestral, monopartite picorna-like insect virus genome, generating independent evolutionary lineages with bipartite genomes.

The most atypical aspect of the BRNV genome is the 189-aa region at the $C$ terminus of the $R d R p$ with homology to the AlkB domain of viruses of the Flexiviridae and members of the genus Ampelovirus of the family Closteroviridae. The source of this unusual sequence is unknown; however, it likely arose from a recombination event between two co-infecting viruses. It is possible that this sequence was integrated from a previously required helper virus, one of which is documented for at least one member of the family Sequiviridae, Parsnip yellow fleck virus (17). BRNV has been detected in multiple species of Rubus (15); therefore, it is possible that the recombination event could have occurred in a different host before moving to Rubus spp. This transfer of genetic material could have conferred an adaptive advantage of the virus to the aphid vector or plant host. Genes for AlkB homologues are prevalent in nature, occurring in eukaryotes, bacteria, and few plant viruses $(3,4)$. Conservation of catalytic residues suggested that these homologues, traditionally thought to protect only DNA against damage from methylating agents, also might modify RNA in a similar way. Enzymatic RNA modifications often are associated with control of gene expression; therefore, it was postulated that, if AlkB could use RNA as a substrate, it could be implicated in defense of posttranscriptional gene silencing (PTGS) (3). Indeed, Aas et al. (1) demonstrated that AlkB can repair alkylation damage in RNA. Thus, perhaps the acquisition and retention of this functional domain supplied BRNV with an adaptive mechanism of counterdefense. This same region has been detected in isolates of BRNV obtained from Ohio and California (15), which reveals that this is not an event unique to Oregon isolates.

Based on aphid transmission results, BRNV is transmitted in a nonpersistent mode by $M$. persicae. The percentage of infected plants increased as A. agathonica feeding times were extended. However, because transmission was successful with feeds of $20 \mathrm{~s}$ to $1 \mathrm{~min}$ for acquisition and inoculation transmission times, A. agathonica also transmitted BRNV in a nonpersistent mode. These trials were performed before the revelation that $\mathrm{BRDaV}$ was a strain of BRNV; thus, we made no presumptions based on previous reports that BRNV was transmitted semipersistently (46).

To verify that BRNV is the causal agent of BRD, the steps of Koch's postulates were undertaken, with modifications for obligate parasites. Greenhouse-grown clonal black raspberry plants infected with BRNV and tested free of other viruses were used as source material. These plants showed mottling and chlorosis symptoms typical of declining black raspberry in fields. Plants with such symptoms consistently tested positive for BRNV via RT-PCR. The characteristic high MW dsRNA doublet and $\approx 35-\mathrm{nm}$ virus-like particles were purified from these plants. After feeding on these infected plants, the large raspberry aphid was used to transmit BRNV to healthy black raspberry. These recipient hosts developed the same mottling and chlorosis, tested positive for BRNV via RT-PCR (which was confirmed by sequencing), and had the same dsRNA banding pattern. In the absence of a fulllength clone of BRNV, Koch's rules are not completely carried out. However, given the overwhelming circumstantial evidence, BRNV appears to be the causal agent of BRD.

Prior to RT-PCR testing, several biological characteristics suggested similarities between the North American isolate and the Scottish isolate of BRNV. Both viruses have a limited experimental host range, are found in low titers in herbaceous plants, and are recalcitrant to purification $(24,34)$. Both infect red raspberry with indistinct or no symptoms (46), and both are transmitted by the large raspberry aphid, though with different transmission modes. Both have similar particle structure consisting of empty and filled particles, though the Scottish BRNV, at $\approx 30 \mathrm{~nm}$ in diameter, reportedly was smaller than the North American isolate (24). Genetic comparison from more geographically distinct isolates will offer more information on the diversity of this virus and, furthermore, will provide insight into the evolutionary dynamics of the AlkB domain.

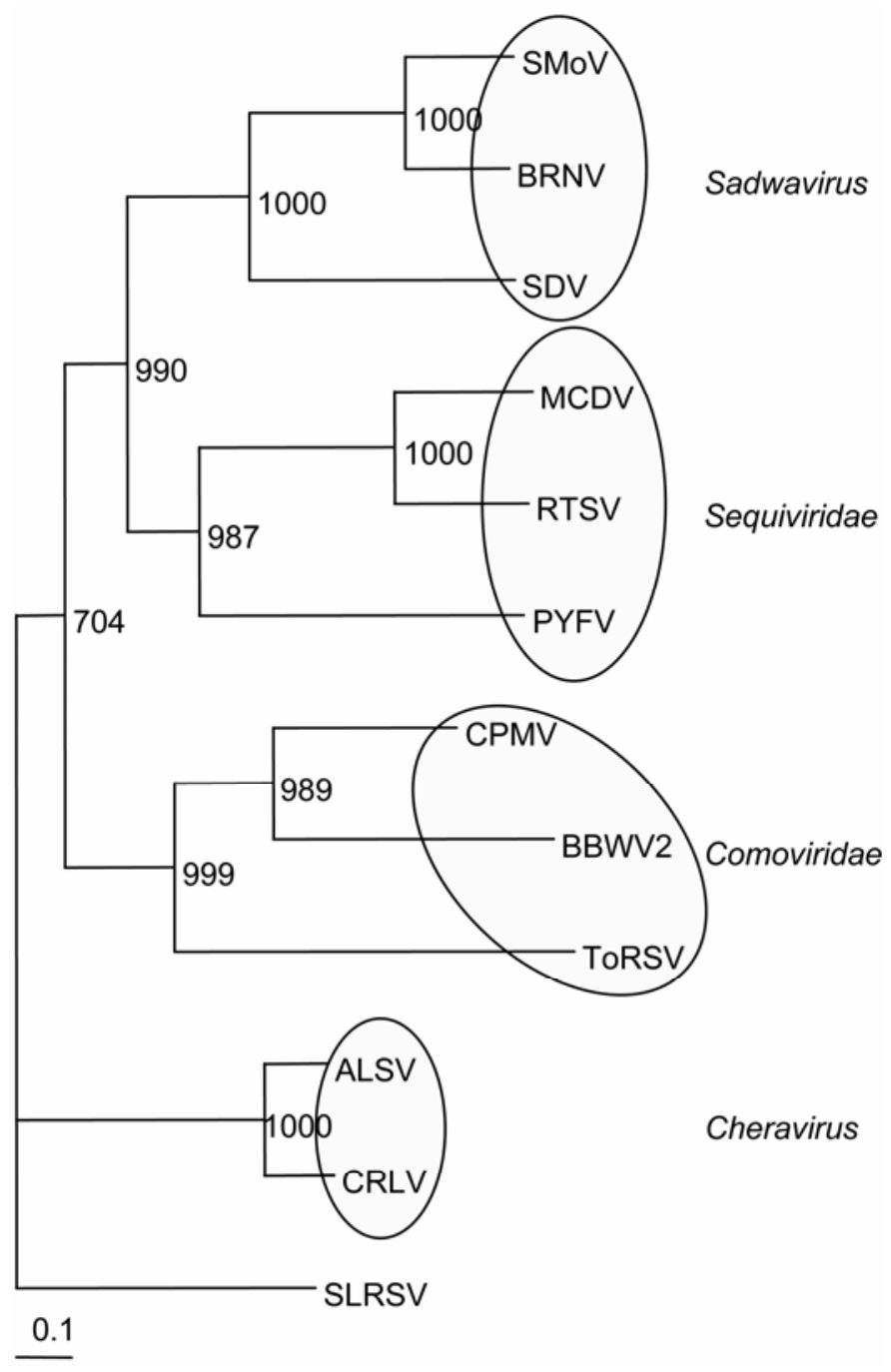

Fig. 5. Unrooted neighbor-joining analysis of the combined conserved regions of helicase, protease, and RdRp of Black raspberry necrosis virus (BRNV) and orthologous regions of related viruses, based on the alignment of amino acids 577-673, 1,214-1,257, and 1,338-1,817 of BRNV open reading frame 1. Abbreviations of virus names and GenBank accession numbers are BRNV, DQ344639; SMoV, Strawberry mottle virus, NP_599086.1; SDV, Satsuma dwarf virus, NP_620566; MCDV, Maize chlorotic dwarf virus, NP_619716.1; RTSV, Rice tungro spherical virus, Q91PP5; PYFV, Parsnip yellow fleck virus, NP_619734.1; BBWV2, Broad bean wilt virus 2, NP_149012; CPMV, Cowpea mosaic virus, NP_613283.1; ToRSV, Tomato ringspot virus, NP_620765.1; SLRSV, Strawberry latent ringspot virus, YP_227367.1; ALSV, Apple latent spherical virus, NP_620568; and CRLV, Cherry rasp leaf virus, AAW92113. Numbers by each node are bootstrap values for 1,000 replicates. The scale bar represents the average number of residue substitutions per site. 


\section{ACKNOWLEDGMENTS}

We thank S. MacFarlane and H. Barker at the Scottish Crop Research Institute, M. Nesson at the Oregon State University Electron Microscope Facility for his technical expertise, the Carrington lab for providing seed for the mutant tobacco, and J. Kraus for many helpful discussions.

\section{LITERATURE CITED}

1. Aas, P. A., Otterlei, M., Flanes, P. O., Vagbo, C. B., Skorpen, F., Akbari, M., Sundheim, O., Bjoras, M., Slupphaug, G., Seeberg, E., and Korkan, H. E. 2003. Human and bacterial oxidative demethylases repair alkylation damage in both RNA and DNA. Nature 421:859-863.

2. Altschul, S. F., Madden, T. L., Schaffer, A. A., Zhang, J., Zhang, Z., Miller, W., and Lipman, D. J. 1997. Gapped BLAST and PSI-BLAST: A new generation of protein database search programs. Nucleic Acids Res. 25:3389-3402.

3. Aravind, L., and Koonin, E. V. 2001. The DNA-repair protein AlkB, EGL9, and leprecan define new families of 2-oxoglutarate- and iron-dependent dioxygenases. Genome Biol. 2(3):research0007.1-0007.8

4. Bratlie, M. S., and Drabløs, F. 2005. Bioinformatic mapping of AlkB homology domains in viruses. BMC Genomics 6:1.

5. Cadman, C. H. 1951. Studies in Rubus virus diseases. I. A latent virus of Norfolk Giant raspberry. Ann. Appl. Biol. 38:801-811.

6. Cadman, C. H. 1952. Studies in Rubus virus diseases. V. Experiments in analysis of Lloyd George decline. Ann. Appl. Biol. 39:501-508.

7. Campanella, J. J., Bitincka, L., and Smalley, J. 2003. MatGAT: an application that generates similarity/identity matrices using protein or DNA sequences. BMC Bioinformatics 4:29.

8. Christian, P., Fauquet, C. M., Gorbalenya, A. E., King, A. M. G., Knowles, N., LeGall, O., and Stanway, G. 2005. Picornavirales: A proposed order of positive sense RNA viruses. ICTV Poster Session at the International Congress of Virology, San Francisco.

9. Clark, M. F., and Adams, A. N. 1977. Characteristics of the microplate method of enzyme-linked immunosorbent assay for the detection of plant viruses. J. Gen. Virol. 34:475-483.

10. de Miranda, J., Shen, M., Cameron, C. E., Stoltz, D. B., and Camazine, S. M. 2004. Complete nucleotide sequence of Kashmir bee virus and comparison with acute bee paralysis virus. J. Gen. Virol. 85:2263-2270.

11. Dolja, V. V., and Koonin, E. V. 1991. Phylogeny of capsid proteins of small icosahedral RNA plant viruses. J. Gen. Virol. 72:1481-1486.

12. Gorbalenya, A. E., Donchenko, A. P., Blinov, V. M., and Koonin, E. V. 1989. Cysteine proteases of positive strand RNA viruses and chymotrypsin-like serine proteases. FEBS Lett. 243:103-114.

13. Gorbalenya, A. E., Koonin, E. V., and Wolf, Y. I. 1990. A new superfamily of putative NTP-binding domains encoded by genomes of small DNA and RNA viruses. FEBS Lett. 262:145-148.

14. Govan, V. A., Leat, N., Allsopp, M., and Davison, S. 2000. Analysis of the complete genome sequence of acute bee paralysis virus shows that it belongs to the novel group of insect-infecting RNA viruses. Virology 277:457-463.

15. Halgren, A. B. Characterization, epidemiology, and ecology of a virus associated with black raspberry decline. Ph.D. diss., Oregon State University, Corvallis.

16. Halgren, A. B., Tzanetakis, I. E., and Martin, R. R. 2003. Characterization of an aphid-transmitted virus associated with black raspberry decline in Oregon. (Abstr.) Phytopathology 93(suppl.):S32.

17. Harrison, B. D., and Murant, A. F. 1984. Involvement of virus-coded proteins in transmission of plant viruses by vectors. Pages 13-14 in: Vectors in Virus Biology. M. A. Mayo and K. A. Harrap, eds. Academic Press, London.

18. Huang, X., and Madan, A. 1999. CAP3: A DNA Sequence Assembly Program. Genome Res. 9:868-877.

19. Iwanami, T., Kondo, Y., and Karasev, A. V. 1999. Nucleotide sequences and taxonomy of satsuma dwarf virus. J. Gen. Virol. 80:793-797.

20. Iwanami, T., Kondo, Y., Makita, Y., Azeyanagi, C., and Ieki, H. 1998. The nucleotide sequence of the coat protein genes of satsuma dwarf virus and navel infectious mottling virus. Arch. Virol. 143:405-412.

21. Jelkmann, W., Martin, R. R., and Maiss, E. 1989. Cloning of four plant viruses from small quantities of double-stranded RNA. Phytopathology 79:1250-1253.

22. Jones, A. T., and Jennings, D. L. 1980. Genetic control of the reactions of raspberry to black raspberry necrosis, raspberry leaf mottle and raspberry leaf spot viruses. Ann. Appl. Biol. 96:119-123.

23. Jones, A. T., and Mitchell, M. J. 1986. Propagation of black raspberry necrosis virus (BRNV) in mixed culture with Solanum nodiflorum mottle virus, and the production and use of BRNV antiserum. Ann. Appl. Biol. 109:323-336.
24. Jones, A. T., and Murant, A. F. 1972. Some properties of a mechanically transmissible virus widespread in raspberry (Rubus idaeus) in Scotland. Plant Pathol. 21:166-170.

25. Karasev, A. V., Han, S. S., and Iwanami, T. 2001. Satsuma dwarf and related viruses belong to a new lineage of plant picorna-like viruses. Virus Genes 23:45-52.

26. Koonin, E. V. 1991. The phylogeny of RNA-dependent RNA polymerases of positive-strand RNA viruses. J. Gen. Virol. 72:2197-2206.

27. Koonin, E. V., and Dolja, V. V. 1993. Evolution and taxonomy of positivestrand RNA viruses: Implications of comparative analysis of amino acid sequences. Crit. Rev. Biochem. Mol. Biol. 28:375-430.

28. Kozak, M. 2002. Pushing the limits of the scanning mechanism for initiation of translation. Gene 299:1-34.

29. Marchler-Bauer A., and Bryant, S. H. 2004. CD-Search: Protein domain annotations on the fly. Nucleic Acids Res. 32:W327-331.

30. Martin R. R., Tzanetakis, I. E., Sweeney, M., and Wegener, L. 2006. A virus associated with blueberry fruit drop disease. Acta Hortic. 715:497-502.

31. Mayo, M. A. 2005. Changes to virus taxonomy 2004. Arch. Virol. 150:189-198.

32. Mayo, M. A., and Fritsch, C. 1994. A possible consensus sequence for VPg of viruses in the family Comoviridae. FEBS Lett. 354:129-130.

33. Melcher, U. 2000. The $30 \mathrm{~K}$ superfamily of viral movement proteins. J. Gen. Virol. 81:257-266.

34. Murant, A. F., Jones, A. T., and Roberts, I. M. 1976. Recent research on $52 \mathrm{~V}$ virus of raspberry. Acta Hortic. 66:39-46.

35. Mushegian, A. R., and Koonin, E. V. 1993. Cell-to-cell movement of plant viruses. Insights from amino acid sequence comparisons of movement proteins and from analogies with cellular transport systems. Arch. Virol. 133:239-257.

36. Ongus, J. R., Peters, D., Bonmating, J. M., Bengsch, E., Vlak, J. M., and van Oers, M. M. 2004. Complete sequence of a picorna-like virus of the genus Iflavirus replicating in the mite Varroa destructor. J. Gen. Virol. 85:3747-3755

37. Oregon Agricultural Statistics Service. 2006. Oregon agriculture: Facts and figures. Published online by the U.S. Dep. Agric.-National Agricultural Statistics Services.

38. Page, R.D.M. 1996. TREEVIEW: An application to display phylogenetic trees on personal computers. Comput. Appl. Biol. 12:357-358.

39. Palmenberg, A. C. 1987. Picornaviral processing: Some new ideas. J. Cell. Biochem. 33:191-198.

40. Ritzenthaler, C., Viry, M., Pinck, M., Margis, R., Fuchs, M., and Pinck, L. 1991. Complete nucleotide sequence and genetic organization of grapevine fanleaf nepovirus RNA1. J. Gen. Virol. 72:2357-2365.

41. Rott, M. E., Tremaine, J. H., and Rochon, D. M. 1991. Comparison of the 5' and 3' termini of tomato ringspot virus RNA1 and RNA2: Evidence for RNA recombination. Virology 185:468-472.

42. Sambrook, J., and Russell, D. W. 2001. Molecular Cloning: A Laboratory Manual. Cold Spring Harbor Laboratory, Cold Spring Harbor, NY.

43. Shi, X. M., Miller, H., Verchot, J., Carrington, J. C., and Vance, V. B. 1997. Mutations in the region encoding the central domain of helper component-proteinase (HC-Pro) eliminate potato virus X/potyviral synergism. Virology 231:35-42.

44. Spiegel, S., and Martin, R. R. 1993. Improved detection of potato leafroll virus in dormant potato tubers and microtubers by the polymerase chain reaction and ELISA. Ann. Appl. Biol. 122:493-500.

45. Stace-Smith, R. 1955. Studies on Rubus virus diseases in British Columbia. I. Rubus yellow-net. Can. J. Bot. 33:267-274.

46. Stace-Smith, R. 1955. Studies on Rubus virus diseases in British Columbia. II. Black raspberry necrosis. Can. J. Bot. 33:314-322.

47. Stace-Smith, R. 1956. Studies on Rubus virus disease in British Columbia. III. Separation of components of raspberry mosaic. Can. J. Bot. 34:435-442.

48. Stace-Smith, R. 1984. CMI/AAB Description of Plant Viruses No. 290. Commonw. Mycol. Inst./Assoc. Appl. Biol., Kew, England.

49. Thompson, J., Higgins, D., Gibson, T., Thompson, J. D., Higgins, D. G., and Gibson, T. J. 1994. CLUSTAL W: Improving the sensitivity of progressive multiple sequence alignment through sequence weighting, position-specific gap penalties and weight matrix choice. Nucleic Acids Res. 22:4673-4680.

50. Thompson, J. R., Leone, G., Lindner, J. L., Jelkmann, W., and Schoen, C. D. 2002 Characterization and complete nucleotide sequence of Strawberry mottle virus: A tentative member of a new family of bipartite plant picorna-like viruses. J. Gen. Virol. 83:229-239.

51. Weber, C. A. 2003. Genetic diversity in black raspberry (Rubus occidentalis L.) detected by RAPD markers. HortScience 38:269-272.

52. Yoshikawa, N., and Converse, R. H. 1990. Strawberry pallidosis disease: Distinctive dsRNA species associated with latent infections in indicators and in diseased strawberry cultivars. Phytopathology 80:543-548. 